\title{
John Hill, Exotic Botany and the competitive world of eighteenth-century horticulture
}

\author{
Sarah Easterby-Smith, University of St Andrews
}

Note: This is the final version of a chapter that will be published in Clare Brant and George Rousseau (eds.), Fame and Fortune: Sir John Hill and London Life in the 1750s (Palgrave). As the edited collection focuses entirely on John Hill's life and work, my chapter assumes that the reader is familiar with Hill and his activities. John Hill (1714-1775) was a physician, actor and prolific writer who, among his diverse publications, wrote extensively about botany in the mid-eighteenth century. Please do not cite or circulate further without permission.

John Hill's first formal entrée into eighteenth-century botany came about as a result of his work as botanical gardener to Lord Petre. While employed at Thorndon Hall between 1736 and 1742, Hill met many of eighteenth-century Britain's most significant scholars of botany. These well-heeled virtuosi visited Petre's garden and conversed not only with the garden's aristocratic proprietor but also with its skilled custodians. ${ }^{1}$ Hill gained a reputation as a knowledgeable member of a burgeoning scholarly community. He forged connections, too, with his fellow gardeners and with commercial plant traders, who were both his peers and his rivals. Unlike most other gardeners, however, Hill used print to articulate his botanical expertise, to assert his credentials as a scholar and thus to gain distinction among his peers. Hill's botanical publications invite us to examine how he constructed his scholarly expertise in print, and how he positioned himself in relation to a wider metropolitan community of botanists, gardeners and commercial nurserymen.

This chapter focuses on just one of Hill's many botanical publications, his lavishly illustrated Exotic Botany Illustrated in thirty-five figures of Curious and 
Elegant Plants: Explaining The Sexual System; and Tending to give some New Lights into the Vegetable Philosophy (1759). The book describes non-native plants recently arrived in Britain, which are arranged according to one of eighteenth-century Europe's newest taxonomic systems, that devised by the Swede Carl Linnaeus (17071778). Exotic Botany is significant for several reasons. It stands out from many of Hill's other botanical publications due to its innovative content and its beauty as an object. $^{2}$ Exotic Botany was written with an upper-end readership in mind and its format and content respond to mid-eighteenth century conventions for 'polite' science. The text sits luxuriously within spacious folio pages and beautiful handpainted plates accompany each description. The book also diverges from most contemporary British botanical literature because it uses Linnaeus's new sexual system. As Brent Elliott explains in Chapter 13, Linnaean taxonomy was little known among British students of botany before the 1760s. The plants in Exotic Botany are arranged according to Linnaean classes, and the accompanying texts explain in English the fundamentals of the new system. It forms a surprising contrast to Hill's later Vegetable System (1761-75), which rejects Linnaeaus's taxonomy but adopts his nomenclature. $^{3}$

In spite of its title, the book places as much emphasis on horticulture as on botany. Hill's Exotic Botany exposes a conceptual link between botany and horticulture that, although rarely articulated explicitly, underpinned both intellectual arenas in the mid-eighteenth century. Hill makes use of this connection to construct and promote his expertise as a botanist. Exotic Botany implicitly invites readers to consider Hill as someone who could combine high-minded botanical theory with lesselevated practical expertise accrued among gardeners. The book was published at a key moment in Hill's life, when he was moving away from the less reputable 
journalism that characterised the middle decades of his career, towards his more respectable engagement with botanical science in the 1760s and 1770s. Reading between the lines of the text, then, tells us as much about Hill as about botany. Exotic Botany reveals how Hill used print to stake his claim as a serious scholar, and to differentiate himself from his horticultural and botanical peers in London in the late 1750 s. $^{4}$

\section{Botany, Horticulture and Polite Science}

Eighteenth-century ideas about botany, horticulture and science diverge from presentday expectations for science and scholarship. The modern disciplines of botany and horticulture were formulated during the Enlightenment; this process involved defining the content of each branch of knowledge and how it should be communicated. Participation in Enlightenment science was also characterised by very different social and cultural expectations about what it meant to be a scholar. Exotic Botany is situated within this milieu, which Hill manipulated to assert his own expertise.

Botany, like most other eighteenth-century sciences, was not a professionalised discipline. The scholarly investigation into plants had been traditionally considered part of medicine. By the eighteenth century, botanical study had broadened out to become an independent branch of natural knowledge that focused primarily on questions of taxonomy and nomenclature. Yet very few paid posts existed for botanists and it was not possible to gain a formal qualification in the science. The majority of botanical scholars, then, were private individuals who devoted varying degrees of spare time to the study of plants. These 'amateurs' could range from wealthy aristocrats such as Lord Petre to men and women of the middling 
ranks. Several botanical amateurs developed very high levels of expertise and participated actively within Enlightenment scholarly networks. ${ }^{5}$

Horticulture, or the science of gardening, became a clearly defined discipline over the eighteenth century. In London, 'gardening' was a trade with its own guild that regulated admission and apprenticeship. Most gardeners were manual labourers and were not required to learn botany. Yet a new 'scientific' approach to gardening gradually emerged, where knowledge about botanical taxonomy, nomenclature and plant physiology underpinned experimentation in plant cultivation. By the turn of the nineteenth century this combination was known as 'horticulture'; ${ }^{6}$ the foundation of the Horticultural Society of London in 1804 gave this new field of knowledge institutional standing. ${ }^{7}$ John Hill's Exotic Botany advocates the value of applying of scientific knowledge to gardening, and vice versa.

But what was science in the Enlightenment? The distinction between 'science' and 'art' was formulated differently from the present day. Activities relating to theory or requiring the systematic application of principles might be described as 'science', while 'art' comprised the practical application of all sorts of knowledge, including agriculture and gardening. ${ }^{8}$ In the early-modern period, furthermore, scholarship of the natural world had been conceived as 'natural philosophy': scholars considered both facts and philosophy about (for example) plants, animals or minerals, without necessarily separating them into the modern disciplines of botany, zoology and mineralogy. The eighteenth century ultimately saw the consolidation of these branches of knowledge into discreet disciplines, complete with norms for their practice and communication. ${ }^{9}$ The eventual emergence of botany and horticulture as defined intellectual fields was the result of the collective work of botanically trained 
gardeners and amateurs of botany over the course of the eighteenth and nineteenth centuries.

The eighteenth century also saw the audiences for science widen from aristocrats to include gentlemen and members of the middling ranks. In Britain the broadening public engagement with the sciences was accompanied by concerns, however, about its effect on the 'polite' culture that was so highly valued among the middling and upper sorts. ${ }^{10}$ While curiosity about the natural world was encouraged among the social groups mentioned above, critics worried that too much scholarship might undermine the foundation of polite society. ${ }^{11}$ 'Deep learning', the Earl of Chesterfield explained in 1749, 'is generally tainted with pedantry, or at least unadorned by manners'. ${ }^{12}$ Exotic Botany satisfies a contemporary need for books on science that offered enough information for polite readers to converse about a subject without going into excessive detail.

The association between the scientific study of plants and their cultivation in gardens meant that botany emerged as a popular science in mid-eighteenth-century Britain at the very same time that the commercial trade in plants expanded. In response to demand from a growing urban consumer public, the number of commercial nurseries advertising in London doubled from fourteen in the period $1700-1740$, to twenty-eight in $1760-1800 .{ }^{13}$ The wealthy created new landscape gardens and invested in the latest hot-house technologies to foster their tender, exotic specimens. Members of the urban middling ranks, including those without gardens, reputedly cultivated as much greenery as possible. ${ }^{14}$ 'At every house in town', enthused Swedish botanist Pehr Kalm on a visit to London in 1748, 
they had commonly planted ... partly in the earth and ground itself, partly in pots and boxes, several of the trees, plants and flowers which could stand the coal-smoke in London. They thus sought to have some of the pleasant enjoyments of a country life in the midst and hubbub of the town. ${ }^{15}$

As I have shown elsewhere, London's better-educated nurserymen helped to whip up public interest in both botany and gardening from the mid-eighteenth century onwards. The commercial nurseries marketed rare plants as specimens of interest to amateurs of botany, and some even offered botanical training either in print or in person through lecture courses. ${ }^{16}$ The expanding public interest in botany and gardening prompted an unusual coupling of commerce with connoisseurship, an amalgamation that maverick Hill was adept at exploiting.

\section{Exotic Botany and Linnaean taxonomy}

Exotic Botany presents a cutting-edge botanical system in a format intended to please the eye and the mind. It focuses primarily on newly arrived plants from China, engaging with the widespread fashion for Chinoiserie that dominated early- to mideighteenth-century culture. ${ }^{17}$ The first edition cost the princely sum of $£ 2.12$ s. 6 d., and Hill states on the title page that it was printed 'at the Expense of the Author'. No additional printer/publisher is named, and Hill actively solicited aristocratic subscribers to support the book. ${ }^{18}$ In December 1758 he told the Earl of Bute that '[t]he Expence [sic] of this has outrun my slender fortune', a fact he continued to

emphasise in letters to other subscribers. ${ }^{19}$ The dedication to Hill's prospective patron, Hugh Percy, the Earl of Northumberland, suggests that the latter may have contributed towards the production costs, as Bute would later agree to do for The 
Vegetable System. ${ }^{20}$ By contrast, the costs of the second edition of Exotic Botany (1772) would be shared by four publishers: R. Baldwin, J. Ridley, Peter Elmsley and Richardson \& Urquhart.

The book's treatment of Linnaeus is innovative for the 1750s. The subtitle announces that it offers 'some New Lights into the Vegetable Philosophy', by which Hill means recent developments in botanical classification. Hill explains in the Preface that he had selected plants 'that served best to illustrate the Sexual System' in other words, examples with which he could explain Linnaeus's new botanical classification. The plants are then ordered according to Linnaean taxonomy. 'The modern system', Hill explains,

invented by LINNÆUS, arranges Plants into Classes, according to their Number, Situation, and Proportion of the dusty Buttons in the Flower, which grow usually upon slender Filaments, about the young Seed Vessel. ${ }^{21}$

Exotic Botany follows the taxonomic order devised by Linnaeus, offering between one and five specimens as examples of each class. The explanations are simplistic but clear. Describing the 'Jacobæan Amaryllis', for example, Hill explains to his readers that

The six Filaments discover the Plant to be of this hexandrous Class; the sixth in order in the Sexual System: and the Character of that Class cannot be more strongly mark'd in any Flower. The ANTHERA, or Buttons, which crown the Filaments, are at first long and white; afterwards shorter and yellow. ${ }^{22}$ 
Exotic Botany does not offer a completely comprehensive treatment of the Linnaean System: there are no individual examples for the seventh and eighth classes, presumably because Hill did not have any suitable specimens. Nevertheless, the book includes entries for most of Linnaeus's twenty-four classes.

Under Hill's guidance the readers of Exotic Botany would become familiar with the basic principles of Linnaean taxonomy. He assists his students by identifying potential points of confusion. The twelfth class, for example, 'is one of the most complex Distinctions of the Linnaean System, and should be well fixed in the Memory'. ${ }^{23}$ The explanations in the book lack detail, however, and do not provide a practical introduction to the new sexual system. Readers would not have been able to apply Linnaean taxonomy themselves, but they would have gained enough 'lights' to profess a basic knowledge of its principles.

Hill is generally remembered as a critic of Linnaean taxonomy, and his decision to arrange Exotic Botany according to the sexual system is surprising. British botanists in the 1750 s and 1760 s were divided over Linnaeus's relentlessly artificial method of arranging plants: his detractors claimed that the classification warped the natural order, misrepresenting the relations between plants. ${ }^{24}$ Hill shared this contemporary scepticism. ${ }^{25}$ Writing about the Linnaean class polyandria in another of his botany books, The British Herbal (1756), he noted that 'Nature separates these plants, [...but] Linneæus joins them. ${ }^{26}$ As Brent Elliott explains in Chapter 13, Hill's opposition to Linnaean classification would extend to him devising his own taxonomy in The Vegetable System, the first volume of which was published shortly after Exotic Botany.

Exotic Botany presents us with a paradox, then, as Hill appears to promote a system that he rejects in his other botanical publications. But the book does not in fact 
offer a wholehearted affidavit for Linnaean taxonomy. Several entries emphasise that 'the Doctrine of the LINNAEAN School ... is not universal in the School of Nature', ${ }^{27}$ and that Linnaeus's classifications were too arbitrary to endure for long. Writing about how the rhubarb had foxed taxonomists for centuries, for example, Hill notes that:

They err'd who plac'd it with the Docks, though its Flowers, Seeds, and whole Habit, naturally might have justified the Mistake in Times when the present Distinctions of Plants were not sufficiently known. The Certain Characters of the sexual System plainly separate it. Perhaps a natural Method will some Time change the Face of Things again. ... the Laws of the Present System, placed it in the ninth Class, the Enneandria. ${ }^{28}$

Hill also works his scepticism about Linnaeus into the book in more subtle ways. He presents himself rhetorically as an expert whose knowledge is more or less equal to that of his Swedish counterpart. The first explanation of Linnaeus's 'modern system', quoted above, does not appear until the end of the first three pages and is notably brief. Likewise, although the descriptions of each specimen usually run to six paragraphs, the specific discussion of Linnaean taxonomy averages a mere two sentences. Hill includes asides that further humble Linnaeus: regarding the twelfth class, he cannot resist adding gleefully that 'the great Author of the System himself once mistook it. ${ }^{29}$ Exotic Botany may be structured according to Carl Linnaeus's taxonomic order, but the botanical authority is unequivocally John Hill.

Hill produced this book for readers who were new to the science of plants. At one point he refers to the 'young Botanist', implying that he envisages his audience as 
inexperienced, if not actually youthful. ${ }^{30}$ The focus is on 'Curious and Elegant' plants - rarities with a clear aesthetic appeal - and the format of the book reflects this aesthetic emphasis. Exotic Botany's illustrations conform to eighteenth-century botanical conventions in so far as they depict plants as single specimens against a white background, so that key features could be seen clearly. The illustrations are ostensibly botanical but most lack the full range of details necessary for a comprehensive examination. The majority of the images do not show plants' roots, and do not include cross-sections of the flowers, for example. By presenting its scientific content in a form that was both aesthetically pleasing and fashionable, the book remained very much in keeping with mid-eighteenth-century norms for polite science. ${ }^{31}$ Its large size and eye-catching illustrations would permit its owners to ostentatiously display their broad intellectual interests.

\section{Horticultural Knowledge}

Although horticulture had not yet come into its own as a distinct intellectual field, Exotic Botany underlines the value of uniting knowledge derived from gardening with that derived from the scientific study of plants. This is the book's second innovative feature, which further differentiates it from many contemporary books on botany.

According to Hill, horticulture was useful in solving the taxonomic questions that preoccupied Enlightenment botanists. 'Experience', he states firmly in the introduction, 'will be the best guide. ${ }^{32}$ The ensuing text underlines that his 'experience' is, literally, down-to-earth. Hill grounds his descriptions of plants in his own practical expertise, using what he had learnt from the garden to clarify, and even correct, contemporary botanical conundrums. Early in the book he discusses the 'Peloria'. Botanists had disputed whether it should be classed as a genuine specimen 
or as a variety (in eighteenth-century terms a 'mongrel'), the product of crossbreeding Veronica and Vervain (Verbena). 'All I can say,' Hill helpfully offers, 'is that I have long cultivated the two Plants in the same Border, and near one another, but no middle kind has yet appear'd. ${ }^{33}$ Hill refers again to the value of practical experience in his discussion of the tea plant [Figure 1]. 'We have long question'd', he writes,

whether the Green and Bohea Tea were, or were not, the produce of the same Shrub: most thought they were [...] I think it is otherwise. [...] Whether this difference be the Case, must be found by Experience: and if they really be the Produce of two distinct Shrubs, we are yet to learn whether the Difference be as Species, or only as Varieties. ${ }^{34}$

Exotic Botany asserts the value to botanical theory of practical knowledge gained in the garden.

The texts that accompany each plate also explain how to cultivate the plant under discussion. The 'Snowy Mespilus', for example,

may be made a very agreeable Article in Clumps and Small Plantations, but as the Value of it will depend upon the fresh Green of the Leaves and the pure Colour of the Flowers, it must have a free Air; and be kept from the Shade of larger Trees. In this Case the Leaves will retain their Verdure in full Perfection; and the Flowers [...] will have much more Beauty ${ }^{35}$

In addition to practical advice Hill also highlights the plants that would 'shew the Course of Nature in constructing DOUBLE FLOWERS [sic], ${ }^{36}$ Double flowers are 
naturally occurring mutations in which additional petals grow in place of stamens and pistils. Most doubles cannot be pollinated, and are difficult to propagate. They were (and are) highly valued by gardeners for their extreme rarity and beauty, but have been subject to little botanical attention. ${ }^{37}$ Linnaean botanists foundered when faced with specimens whose sexual organs had disappeared - this technically made them unclassifiable - and they dismissed these beautiful sports of nature as unscientific distractions. ${ }^{38}$ Hill does not assert that double flowers should be considered as genuine botanical specimens: Exotic Botany describes the original (non-mutated) plants. He does make clear to his readers, however, which were more likely to produce beautiful, non-botanical blooms.

Further confirming the association between botany and horticulture, Hill stresses anything that could make 'a very valuable Article in our Collections' ${ }^{39} \mathrm{He}$ envisages here ornamental (rather than botanical) gardens in which collections of new exotic specimens were a particular feature. ${ }^{40}$ Exotic Botany would enable its polite readers to select plants whose value was derived from their rarity and aesthetic beauty. The emphasis placed on these atypical blooms gestures towards the existence of a subculture of flower-appreciators. These wealthy admirers of nature sought to acquire a basic knowledge of current science and to collect beautiful plants for their gardens. $^{41}$

The creation of such tasteful collections depended on the circulation of specimens as well as knowledge. Hill takes great care in Exotic Botany to credit the private collectors who had supplied him with the plants depicted in the book. As he explains in the Introduction, he has noted beside each image ' $[\mathrm{t}]$ he place whence I received each [plant]' ${ }^{42}$ His suppliers include aristocrats such as the Earl of Northumberland ${ }^{43}$ and prelates including the Danish-Norwegian bishop Erik 
Pontoppidan. ${ }^{44}$ Several plants were collected directly from fields and gardens in China or elsewhere by 'Gentlemen'. ${ }^{45}$ The book evokes an impressive correspondence network that stretched from Britain to China. ${ }^{46}$ Hill explains to his readers, furthermore, that he would regularly redistribute exotic seeds among the proprietors of other British gardens: 'The Seeds of these Plants came over [to me] with the Specimens; and they [were sent to ...] four remote Parts of the Kingdom, where I have Correspondence with those who have Stoves'. ${ }^{47}$ Hill portrays himself at the centre of a botanical exchange network, receiving, studying and then reallocating precious specimens. $^{48}$

London's horticultural community is also presented as a key source of information, especially regarding vernacular names and practical information about plant cultivation. Hill treats this lower-class community very differently, however, compared to his more elite correspondents. The allusions to gardeners' knowledge are rather vague, and informants are not named individually. A footnote to the description of the 'Blood Stained Hypericum' explains that 'It is discover'd, since Linnæus publish'd his Species [Plantarum], therefore it has not yet been nam'd, except by Gardeners. ${ }^{49}$ On the 'Heroic Piony', he explains that 'our Gardeners have, in the Course of many Ages, rais'd the vast double Flower of the same Name', ${ }^{50}$ and he notes later that 'Our Gardeners know how essential this free Course of the Air is to the Perfection of Fruits'. ${ }^{51}$ The community from which Hill had obtained this practical horticultural advice is presented as part of his network, but as socially differentiated from Hill and his scholarly associates. ${ }^{52}$

Hill does, however, repeatedly name one individual member of this community. Hammersmith nurseryman James Lee (1715-1795) [Figure 2] is mentioned throughout the book, and receives Hill's highest praise. Lee, Hill 
emphasises, was 'a very excellent Gardener ${ }^{53}$ with an exceptional ability to bring tender exotic plants to astonishing levels of 'Perfection'. ${ }^{54}$ Lee was a leading member of the community of gardeners and plant traders mentioned above, and his Vineyard Nursery (which he ran jointly with business partner Lewis Kennedy) was ultimately credited with the introduction of hundreds of new plants into British gardens. ${ }^{55}$ Like Hill, Lee was an early convert to the Linnaean System and, unlike the gardeners mentioned above, he also published on botany. His Introduction to Botany (1760) translated Linnaeus's Philosophia Botanica into English; the low price of the book and its plain language made Linnaean science accessible to a socially diverse readership for the first time. ${ }^{56}$ Lee's work as a supplier was underpinned by extensive horticultural skill and botanical knowledge, which Hill underlines in his various encomiums to the nurseryman.

James Lee and a handful of other commercial nurserymen (including James Gordon (c. 1708-1780), with whom Hill had worked while at Thorndon) represent an elite subsection of the metropolitan horticultural community. Enlightenment scholars appreciated the distinct forms of expertise developed among these well-educated nurserymen and gardeners. Amateurs of botany (who included some of the intended readers of Exotic Botany) visited London's nurseries with the explicit intention of conversing with the gardeners there, and thus learning from them. ${ }^{57}$ These interactions have their roots in the seventeenth century, when commercial nurseries were first established in significant numbers in the capital city. This practice continued and extended over the eighteenth century, thanks to the further increase in the number of commercial nurseries within London, and as public interest in studying botany and horticulture soared. ${ }^{58}$ The knowledge that the upper-end nurserymen were developing 
was a form of 'hybrid expertise', in which theoretical botanical knowledge was complemented by practical horticultural skill. ${ }^{59}$

A corollary of the cultural valorisation of hybrid expertise was a rise in the status accorded to well-educated gardeners. The Royal Society's shifting attitude illustrates this trend. As early as 1667, Thomas Sprat had celebrated the knowledge of 'artisans, countrymen, and merchants' in his History of the Royal Society, asserting that this was superior to that of 'scholars'. ${ }^{60}$ By 1720 (while six-year-old John Hill was out botanising in the Northamptonshire fields) London nurseryman Thomas Fairchild (1667-1729) was invited to attend a meeting of the Royal Society at which his experimental horticultural research was discussed. However, as historian Richard Coulton has shown, the assembled Fellows did not actually expect the nurseryman to speak; instead, his patron and promoter Richard Bradley (1688?-1732) communicated Fairchild's work to his peers. ${ }^{61}$ But the value placed on practical knowledge increased, and attitudes changed accordingly. The London cloth merchant and plant trader Peter Collinson (1694-1768), for example, was made Fellow of the Royal Society in 1728; his credentials for election were founded on a similar combination of practical and intellectual expertise that Thomas Fairchild had developed, and which Hill later espouses in Exotic Botany. ${ }^{62}$ London's horticultural community was responsible for pioneering research into plant physiology, growth and form. The credit accorded to its members gradually increased over the early eighteenth century. John Hill used Exotic Botany to promote the value to Enlightenment botany of his, and others' hybrid knowledge.

\section{Competition and Distinction}


Membership of mid-eighteenth-century London's horticultural community came, however, with its own complications. The upper-end plant traders who sought to make a commercial profit by trading in botanically interesting plants occupied the unenviably uncomfortable position of being both collaborators and competitors. In this respect their situation was parallel to that experienced by members of the Republic of Letters. Upper-end traders such as James Lee sought to participate respectably in botanical circles, seeking to join a scholarly community with an international remit. The culture of Enlightenment scholarship, however, was dominated by a commitment to openness. A scholar would exchange specimens and information as gifts. Hill's proud statement about his willingness to redistribute the exotic seeds he received would situate him within this culture of generous information exchange. But the members of London's horticultural community also sought custom from an increasingly discerning public, and they sought patronage from their scholarly or social superiors. Canny plant traders and socially aspirant amateurs needed to distinguish themselves over and above their peers, but also sought to uphold a respectable reputation as knowledgeable associates. They consequently engaged in forms of self-promotion that were characterised more by tact and discretion than by overt aggrandizement. ${ }^{63}$ The methods used to achieve this are, again, evoked within the pages of Exotic Botany.

The ways in which commercial nurserymen competed varied according to practitioners' social positions and educational levels. Those lower down the profession - the 'lesser sort' referred to above - often claimed consumers' attention by naming plant varieties after themselves, through which they might effectively continue to advertise their own nursery long after a plant had been sold. In a catalogue of Lancashire gooseberries from 1780, for example, three quarters of the 319 
gooseberry varieties were named after a specific cultivator. The catalogue listed gooseberries named 'Red Mogul' and 'White Mogul' but also 'Mather's White Mogul' and 'Thorp's White Mogul'. ${ }^{64}$ The gardeners and nurserymen who were well versed in botany pursued a very different strategy. They sought to elevate themselves above their competitors by refraining from engaging in direct competition with each other, presenting themselves instead as respectable participants in botanical networks. ${ }^{65}$ Hill may have been an irrepressible self-promoter, but within a scholarly context at least he presents himself as relatively modest. His discoveries speak for themselves - more or less.

Hill followed the pattern already established by the upper-end gardeners and commercial nurserymen. He, too, embedded his natural competitiveness within claims to scholarly erudition, distinguishing himself from others by asserting his claim to botanical authority rather than by engaging in more underhand commercial competition. He manages to do this in Exotic Botany despite the fact that the book was not intended as a detailed work of science. Hill's claims to superiority are subtle, but nevertheless evident.

Exotic Botany features a genus that Hill claims to have discovered, and which, therefore, needs a scientific name [Figure 3]. The convention among Linnaean botanists was that Carl Linnaeus himself would name new discoveries, though he often used the moniker proposed by whoever had found the specimen. It was customary, furthermore, to devise a name by adapting the surname of a fellow botanist. Linnaean nomenclature consequently became a means of conferring honour (and therefore expressing authority) among botanists. Hill, however, refuses to obey the established convention. 'Men will wonder', he wrote, 'that I have not follow'd the Custom of modern Writers, and nam'd it for my Patron; or from some Friend who 
could return the Compliment. But [... a] Name is useful when it coveys some idea of the Plant: I have therefore call'd this LEPIA., ${ }^{66}$ Driving the point home, Hill continued by explaining that,

I have comply'd so far with Custom, as to deduce it from the GREEK; but in the common Practice of naming Plants from Men, the folly is extream, and the Flattery fulsome. All laugh to hear a Tulip call'd the King of PRUSSIA, or an Auricula Prince FERDINAND. Why is the Ridicule less to name other Plants Mitchella, or Milleria; Catesbæa, or Collinsonia? The Botanist that can't preserve his Name by better Marks, does not deserve that it should be remember'd. ${ }^{67}$

Hill's criticism here is directed at two groups. Firstly he dismissively condemns breeders who gave fanciful names such as 'King of Prussia' or 'Prince Ferdinand', to cultivars (cultivated varieties). Flowers such as tulips and auriculas were known as florists' flowers and were collected across Britain by members of the middling ranks, especially artisans. ${ }^{68}$ Like the gooseberries mentioned above, florists characteristically invented overblown names to promote their plants, styling them in ways that gestured either towards exoticism or to their status as semi-luxuries. Hill attacked this lower-class practice as ridiculous because it attributed excessive associations to the flowers in question. ${ }^{69}$

Hill's second criticism was directed towards botanists who commonly named plants after each other: 'Mitchella', 'Milleria', 'Catesbaea', 'Collinsonia'. Underpinning Hill's strictures was a critique of the system of honours within which Linnaean botanical scholarship had become enlaced. The customs that defined 
botanical naming were embedded within conventions in which the decision to name a plant was determined by someone who wielded authority - as a patron and as a scholar - over the wider network. Hill presents this practice as vainglorious and overblown, and thus not dissimilar from the immodest way in which traders named their cultivars. In naming his purported discovery 'Lepia', Hill asserts that he would no longer play the game according to the same rules as his botanical counterparts.

But Hill walked a fine line. He rejected one type of patronage - that emerging within Linnaean botanical networks. But he clung hard onto another - that exerted by aristocratic patrons whose authority and eminence was derived from their social position and not from any claim to scholarly proficiency. The book almost sighs with sycophantic paeans to Northumberland, Hill's own would-be patron, who in Hill's eyes was a 'great Friend and Patron, the Patron of all useful studies' ${ }^{70} \mathrm{He}$ also dedicated one of the book's most stunning images, that of the Poinciana, to Northumberland [Figure 4]. The specimen had apparently flowered at Northumberland's seat where, according to Hill, the 'stoves' (or hothouses) 'are better proportioned for this Service, than any I have seen', and where Northumberland 'who has been so happy in his Attention to this Science, as to enrich EUROPE with more new Plants than could have been expected in the Time, and in the present State of BOTANY; so much having been attempted every where. ${ }^{, 71}$

Hill uses Exotic Botany to aggrandize himself in contrast to other Linnaean botanists, and indeed compared to Linnaeus himself. By presenting himself as a skilled authority, the book prepares the way for the publication of Hill's own taxonomy in The Vegetable System. But the book also reaffirms Hill's dependence on aristocratic support for all his scholarly endeavours. 


\section{Conclusion}

John Hill's Exotic Botany was produced for affluent amateur readers who sought books that presented scholarly information in an aesthetically attractive way. Its tasteful presentation and simple explanations of Linnaeus's system respond to values central to polite culture in the mid-eighteenth century.

The book is significant for its novel treatment of natural knowledge. It stands out for its usage of Linnaeus: Hill translated and explained the new sexual system, but simultaneously incorporated a critique of the taxonomy devised by the so-called 'Father of Modern Botany'. Exotic Botany is perhaps even more noteworthy, however, for its integration of practical horticultural expertise and botanical knowledge. Its texts are testaments to the mutual benefits to be gained from combining both fields of knowledge. A further distinction is the book's attention to flowers that are aesthetically appealing but that fall outwith the parameters of taxonomic botany. Historians often describe eighteenth-century flower breeding as an activity practiced only among the lower classes, namely the artisan florists and gooseberry-growers discussed above. ${ }^{72}$ The wealthy readers of Exotic Botany also sought out unusual blooms, including those considered to be irrelevant to scientific study. ${ }^{73}$ This group of flower appreciators was socially and culturally distinct from the artisan florists and gardeners, but nevertheless relied on their practical horticultural skill. Hill presents himself as a key intermediary between these different social groups, communicating horticultural findings to his elite readers. ${ }^{74}$

George Rousseau's biography examines how Hill negotiated the competitive commercial world of the press, located in Grub Street. This chapter's closing section entered an arena in which competition was played out on very different terms. Entrepreneurial traders and scholars within the Republic of Letters certainly sought to 
gain an edge on their rivals, but avoided direct expressions of antagonism at all costs.

Like the elite nurserymen, Hill refrained from engaging in directly competitive behaviour, and sought distinction instead through his contributions to scholarship, and through courting aristocratic patronage.

${ }^{1}$ Rousseau, Hill, 16-17.

${ }^{2}$ In 1758-9 Hill published at least one herbal or botanical book a month. Rousseau describes these as 'potboilers'. Rousseau, Hill, 242.

${ }^{3}$ As in The Vegetable System, Hill uses vernacular English versions of Linnaean binomials for most of the plants in Exotic Botany. The footnotes give Latin names devised by botanists such as Linnaeus and Tournefort.

${ }^{4}$ For more on how Hill used publication, especially the press, to construct his medical authority see: Rousseau, 'Stung' (1998), esp. 182-183.

${ }^{5}$ On eighteenth-century botany, start with: Jardine, Secord and Spary (1996); Drayton (2000); Spary (2000). On botanical amateurs, see Easterby-Smith (2013).

${ }^{6}$ The word 'horticulture' has existed in English since the late seventeenth century, but acquired explicitly scientific connotations over the course of the eighteenth century. Lustig (1997), 1-2.

${ }^{7}$ The Horticultural Society of London became the Royal Horticultural Society in 1861.

8 'Science, n.'. OED Online. December 2015. Oxford University Press. http://www.oed.com/view/Entry/172672 (accessed January 12, 2016); 'art, n.1'. OED Online. December 2015. Oxford University Press. http://www.oed.com/view/Entry/11125 (accessed January 12, 2016).

${ }^{9}$ The precise timing when 'natural philosophy' was separated into discreet sciences is the subject of historiographical debate. Start with: Porter (2003), 14-15; Gascoigne (2003): 285-304; Yeo (1991): 24-49, esp. 43-44.

${ }^{10}$ On the social divisions within eighteenth-century British society, and especially the reach of polite culture into the middling ranks, start with: French (2000): 277-293; Klein (2012): 27-51.

${ }^{11}$ Whitaker (1996), 75. On polite science, start with: Walters (1997): 121-154; Shapin (1991): 279-327; Porter (1981): 1-18.

${ }^{12}$ Chesterfield to his son, 12 September 1749, quoted in Shapin (2003), 172.

${ }^{13}$ These figures are from archival research I have undertaken for my book,

Cultivating Commerce, Chapter 1. The figures improve on those given in Harvey (1973).

${ }^{14}$ On the expanding number of gardens in and around eighteenth-century London, start with: Longstaffe-Gowan (2001); Laird (1999).

${ }^{15} \mathrm{Pehr}$ Kalm, 'Small yards to each house', 25 June 1748, in Kalm (1892), 85.

${ }^{16}$ Easterby-Smith, Cultivating Commerce, Chapters 1 and 2.

${ }^{17}$ On the eighteenth-century British taste for Chinoiserie, start with: Sloboda (2014), esp. Chapter 4; Porter (2010).

${ }^{18} \mathrm{LPH}, 104,105,108,113,115$.

${ }^{19} \mathrm{LPH}, 104,113$. 
${ }^{20}$ Rousseau, Hill, 271. The Earl of Northumberland was granted a dukedom by George III in 1766, and the dedication in the second edition of Exotic Botany (1772) accordingly address Northumberland as a Duke. For Northumberland's meteoric rise to political prominence, and on his relationship with Bute, start with: Cannon (2004)

${ }^{21}$ Hill, Exotic Botany [EB], 2.

${ }^{22} \mathrm{~EB}, 9$.

${ }^{23} \mathrm{~EB}, 18$.

${ }^{24}$ Stafleu (1971); Koerner (1999).

${ }^{25}$ Rousseau, Hill, 216-217.

${ }^{26}$ Hill (1756), 1.

${ }^{27} \mathrm{~EB}, 20$.

${ }^{28} \mathrm{~EB}, 15$.

${ }^{29} \mathrm{~EB}, 18$.

${ }^{30} \mathrm{~EB}, 15$.

${ }^{31}$ Spary (2004); Wragge-Morley (2016); Easterby-Smith (2013).

${ }^{32} \mathrm{~EB}$, Introduction.

${ }^{33} \mathrm{~EB}, 8$.

${ }^{34} \mathrm{~EB}, 21$.

${ }^{35} \mathrm{~EB}, 17$.

${ }^{36} \mathrm{~EB}$, Introduction.

${ }^{37}$ Meyerowitz, Smyth and Bowman (1989), 209-210.

${ }^{38}$ The rejection of double flowers was also founded on class-based assumptions: the art of breeding fanciful ornamental flowers was known as 'floristry', and was practiced by artisans. George (2007), 156-165.

${ }^{39} \mathrm{~EB}, 2$.

${ }^{40} \mathrm{~EB}, 2$.

${ }^{41}$ Easterby-Smith (2013).

${ }^{42} \mathrm{~EB}$, Introduction.

${ }^{43}$ EB, 16,17, 21, 28.

${ }^{44}$ Erik Pontoppidan (1698-1764) was bishop of Bergen from 1747. His Linnaean Natural History of Norway was published in the early 1750s. Bregnsbo (2002); EB, 8. ${ }^{45} \mathrm{~EB}, 13$.

${ }^{46} \mathrm{~EB}, 8$.

${ }^{47} \mathrm{~EB}$, Introduction.

${ }^{48}$ On the formation of botanical exchange networks in the eighteenth century, start with: Spary (2000), Chapter 2.

${ }^{49} \mathrm{~EB}, 28$.

${ }^{50} \mathrm{~EB}, 20$.

${ }^{51} \mathrm{~EB}, 6$.

${ }^{52}$ For more on how naturalists negotiated class differences see Secord (1994a): 383 408.

${ }^{53} \mathrm{~EB}, 29$.

${ }^{54} \mathrm{~EB}, 5$. Lee is also credited as the cultivator of the Crimson Hibiscus on p. 24.

${ }^{55}$ On James Lee, see: Willson (1961), Jackson, (2004); Easterby-Smith, Cultivating Commerce, Chapters 1 and 2.

${ }^{56}$ Lee (1760).

${ }^{57}$ Easterby-Smith, Cultivating Commerce, Part 3.

${ }^{58}$ For the development of commercial nursery gardens, see: Thick (1998); Coulton (2005); Harvey (1974). 
${ }^{59}$ On 'hybrid expertise', see: Klein and Spary (2010).

${ }^{60}$ Thomas Sprat, History of the Royal Society (1667), quoted in Drayton (2000), 36.

${ }^{61}$ Coulton (2005), 179-180. Richard Bradley had been elected FRS in 1712. Egerton (2005).

${ }^{62}$ On Peter Collinson, see: Swem (1949). On the rising social positions of head gardeners, see: Musgrave (2007).

${ }^{63}$ Easterby-Smith, Cultivating Commerce, Chapter 2.

${ }^{64}$ Maddox (1780), 115-118; Secord (1994b), 276, 285.

${ }^{65}$ Easterby-Smith (2013), 535-537. Natural history traders, quack doctors and other medical practitioners used similar promotional techniques. See: Dietz and Nutz (2005), 64-65; Barry (1987), 29, 31, 33-34.

${ }^{66}$ EB, 29. 'Lepia' (Zinnia L.) means 'fish scales' in Modern and Ancient Greek. I am grateful to Dr Konstantinos Zafeiris for assistance with translating the word and checking its etymology. See also LPH, 76, 78.

${ }^{67} \mathrm{~EB}, 29$.

${ }^{68}$ George (2007), 156-165.

${ }^{69}$ Linnaeus also expressed the same critique. See George (2007), 161.

${ }^{70} \mathrm{~EB}, 5$.

${ }^{71} \mathrm{~EB}, 16$.

${ }^{72}$ George (2007), 156-165.

${ }^{73}$ Easterby-Smith (2013).

${ }^{74}$ For more on the problems of communicating botanical knowledge between lowranking gardeners and florists and socially-elite botanists, see: Gilmartin (2015), 4345 . 